\title{
GOMBATERMESZTÉS FOGLALKOZÁSI BETEGSÉGEI
}

\section{OCCUPATIONAL DISEASE OF MUSHROOM GROWING}

\author{
Almádi Bernadett ${ }^{1}$, Rezsabek Tamás ${ }^{2}$, Szarvas József ${ }^{3}$ \\ ${ }^{1}$ Szent István Egyetem, Gazdaság és Társadalomtudományi Kar, Cím: 2100 Gödöllö, \\ Páter Károly út 1. Telefon / Fax: +36-28-522-000 bernadett.almadi@gmail.com \\ ${ }^{2}$ Szent István Egyetem, Gépészmérnöki Kar, Cím: 2100 Gödöllö, Páter Károly út 1. \\ Telefon / Fax: +36-28-522-000, rezsabek.tamas@gek.szie.hu \\ ${ }^{3}$ Mushroom Spawn Plant and Strain Research Laboratory, Biokékes Nonprofit Ltd., \\ H-3395 Demjén, Top.Nr.0287/8. Hungary.szarvasjozsef@hotmail.com
}

\begin{abstract}
People working in mushroom production are exposed to different hazards such as biological, chemical and physical ones. Hypersensitive pneumonitis (HP) that can cause respiratory allergy poses the greatest risk. A typical work-related disease is lung infection and allergic reaction. Allergic hypersensitivity can be classified in five different groups. The agents, problems, symptoms of hypersensitive pneumonia as well as its nosology are presented. The most frequent work-related diseases are farmer lungs and mushroom grower lungs.
\end{abstract}

Keywords: mushroom growing, occupational disease, hipersensitiv pneumonitis.

\section{Összefoglalás}

A gombatermesztésben dolgozó emberek ki vannak téve különböző veszélyeknek. biológiai, kémiai és fizikai értelemben egyaránt. Legnagyobb kockázata a légúti allergiás megbetegedést kiváltó hiperszenzitív pneumonitist (HP)-nek van. Jellemző munkahelyi ártalom a tüdő megbetegedése, allergiás reakció. Az allergiás túlérzékenység öt különböző típusba sorolható. A túlérzékenységi tüdőgyulladást kiváltó anyagok, panaszok, tünetek és kórisme kerül bemutatásra. Az ágazatban leggyakrabban előforduló munkahelyi ártalom a farmertüdő és a gombatermesztő tüdő.

Kulcsszavak: gombatermesztés, foglalkozási megbetegedés, túlérzékenységi tüdögyulladás.

\section{Bevezetés}

A második világháború elött a világ harmadik legnagyobb gombatermesztője Magyarország volt, 1938-ban 1200 tonna megtermesztett mennyiséggel Franciaország és az Egyesült Államok mögött. Magyarországon még 1940-ben is $200.000 \mathrm{~m}^{2}$ en folyt a termesztés, majd a háború után ez a mennyiség jelentősen visszaesett [1]

Magyarországon a termesztés az évek, évtizedek során visszaesett, jelenleg mint- egy 20.000 tonna gombát termelnek évente és köszönhetően az Új Magyarország Vidékfejlesztési Programnak a termelés csökkenése mára megállt, a szándék az, hogy 50000 tonna mennyiségre növekedjen a termesztés. A fejlesztési szándék kiterjed a belföldi fogyasztás élénkítésére export bövítésre, új gombatermesztő farmok létesítésére, gombakomposzt előállítókra és a feldolgozó kapacitás jelentős növelésére is. A fejlődés miatt fontosnak találtuk egy tanul- 
mányban összegezni a gombatermesztés foglalkozási betegségeit.

\section{Gombatermesztés foglalkozási betegségei}

A gombatermesztésben dolgozó emberek ki vannak téve különböző veszélyeknek, mint biológiai, kémiai és fizikai értelemben egyaránt, ezért úgy gondoljuk, hogy minden e területen dolgozó embernek ismernie kell a termesztés minden fázisában lehetséges veszélyeket. Legnagyobb kockázata a légúti allergiás megbetegedést kiváltó hiperszenzitív pneumonitist (HP)-nek van.

A HP csoportban foglalt betegségeket a foglalkozás alapján vagy a belélegzett por alapján nevezték el. pl: laboratóriumi dolgozók betegsége, farmertüdő, famunkástüdő, szaunázó-tüdő,gabonamunkás tüdő, gombatermesztő tüdő, stb. A továbbiakban szeretnénk bemutatni a gombatermesztési ágazatban fontos kockázatokat, különös tekintettel a farmer- és a gombatermesztótüdőről kívánunk részletesebben írni.

\section{Túlérzékenységi reakciók}

Az allergiás reakciók (túlérzékenységi reakciók) normális esetben ártalmatlan anyagokra adott nem megfelelő immunválaszok.

Normális esetben az immunrendszer melyet antitestek, fehérvérsejtek, hízósejtek, komplement fehérjék és más anyagok alkotnak - megvédi a szervezetet az idegen anyagokkal (antigének) szemben. Arra hajlamos egyénekben azonban az immunrendszer bizonyos - a legtöbb ember számára ártalmatlan - antigénekre (ún. allergénekre) túlzott mértékben reagálhat. Az eredmény allergiás reakció.

A foglalkozási betegségek közül a farmertüdő a mezögazdasági dolgozók 3-7\%ában, a madártenyésztő tüdő a galambászok 6-25, pulykatenyésztők 10-20\%-ában fordul elö. Hazánkban a gombatermesztő tüdőbetegségről nincsenek adatok.
Feltételezhető, hogy a komposztálási folyamatban, termesztésben, komposztszállításban, ki- és betermelést végző személyeknél előfordul a probléma.

A teljesség igénye nélkül, röviden szeretném ismertetni az allergiás reakciók típusait

Gyakoribb I-es típusú túlérzékenységi reakciók: Anafilaxiás sokk, ami tüdőödémához, fulladáshoz, halálhoz is vezethet. Kialakulhat asztmás roham, köhögés. Ilyen pl: szénanátha. Kiváltó allergének: gyógyszerek, inhalatív allergének, rovarok.

A II.-es típusú túlérzékenységi reakciók a transzfúziós reakciók. Kiváltó allergének a gyógyszerek stb. [2].

A szervezetben folyamatosan jelennek meg az immunogén antigének, melyek az immunrendszert celluláris és humorális immunválaszra késztetik és ennek következtében antigén-ellenanyag komplex, azaz immunkomplex keletkezik. PI: farmertüdő, gombatermesztő-tüdő betegség, stb.) Kiváltó gyakoribb allergének: gyógyszerek, baktériumok, konzerválószerek, élelmiszerszínezékek. vírusok. ezek tartoznak a III.-as típusú túlérzékenységi reakciók közé. Részben ide tartozik a farmertüdő betegség, gombatermesztő-tüdő betegség, stb., melyekről a későbbiekben még részletesen lesz szó.

A IV-es típusú túlérzékenységi reakciók közé tartoznak a helyi reakciók, úgy mint a börpír, duzzanat stb. 4-72 óra elteltével fejlődik ki, ezért késői típusú túlérzékenységi reakciónak is nevezzük. Főként intracelluláris paraziták, vírusok, baktériumok, gombák okozta fertőzések ellen nyújt védelmet [2].

V-ös típusú túlérzékenységi csoportba tartozik minden olyan reakció, amelyet antitestek váltanak ki, de a reakció nem az antigén megsemmisítését célozza, illetve eredményezi. 


\section{Hipersensitive pneumonitis (HP)}

A HP számos pulmonalis interstitialis betegség gyüjtőneve, melynek kiváltó oka ismert. A túlérzékenységi tüdőgyulladás a tüdő kis léghólyagjaiban és a legkisebb légutakban, a hörgöcskékben, valamint azok körül zajló gyulladás.

Kétféle hiperszenzitív reakció alakulhat ki a tüdőben: asztma és allergiás alveolitis. Néha egyazon anyag inhalációja esetén mindkét betegség kialakulhat ugyanabban a személyben [3].

A legtöbb esetben a kiváltó ok az inhalált gombaspóra[3] .

Típusosan 4-8 órával a belégzését követően láz, köhögés, hidegrázás és légszomj lép fel. A kilégzési nehezítettség nem jellemző. Ha a beteg a már nem érintkezik az antigénnel, akkor a tünetek általában egykét napon belül javulnak, de a teljes gyógyulás heteket vehet igénybe. Túlérzékenységi tüdőgyulladás formáit és tüneteit az 1 . számú táblázatban szemléltetjük:

1. táblázat. Túlérzékenységi tüdőgyulladás tünetei és formái

\begin{tabular}{|c|c|c|c|}
\hline \multicolumn{4}{|c|}{ Hiperszenzitív pneumonitis klinikai formái } \\
\hline & Akut & Szubakut & Krónikus \\
\hline Antigénexpozíció & $\begin{array}{c}\text { Rövid, } \\
\text { intenzív }\end{array}$ & $\begin{array}{c}\text { Alacsony } \\
\text { dózisú }\end{array}$ & $?$ \\
\hline Köhögés & + & + & + \\
\hline Nehézlégzés & + & + & + \\
\hline Láz & + & + & - \\
\hline Fáradékonyság & - & $+/-$ & $+/-$ \\
\hline Fogyás & - & + & + \\
\hline Idó & $4-6$ óra & Krónikus & Krónikus \\
\hline Fibrosis & - & - & + \\
\hline Progresszió & - & - & + \\
\hline
\end{tabular}

(Orosz nyomán, 2000)

A legjobb megelőzés, ha a beteg elkerüli az antigént, de ha nem tud munkahelyet változtatni, akkor ez nem járható út.

A tünetek kiújulását a porexpozíció megszüntetésével vagy mennyiségének csökkentésével, védőmaszk viselésével esetleg meg lehet akadályozni.

A heveny túlérzékenységi pneumonitiszben szenvedők általában meg- gyógyulnak, ha kerülik a kiváltó anyaggal a további kontaktust. Az antigén hosszas vagy ismételt belégzése fokozatos állapotromláshoz és visszafordíthatatlan betegséghez vezethet.

\subsection{Farmertüdő}

A mezőgazdaságban dolgozóknál elsőként 1932-ben figyelték meg a farmertüdő megbetegedést.

Hátterében inhalált termofil aktinobaktériumok állnak. Nagy számban fordulnak elő komposztban, talajban az élelmiszerekben, de a levegőben és vízben is megtalálhatók.

A gombatermesztésben leggyakrabban elöforduló taxonok: Micropolyspora faeni, (Faenia rectivirgula), Thermoactinomycetes vulgaris, Th. viridis, Th. candidus, Nocardia ssp., Streptomyces spp., Thermomonospora ssp., Thermobifida alba, Th. cellulolytica, stb. [3], [4].

Ilyen expozícióval kell számolni a penészes széna, szalma, alom, komposzt forgatásakor, főleg zárt, rosszul szellőző helyiségekben, raktárakban, tárolókban, gabonaraktárakban, gabonasilók megnyitásakor, állatok almozásakor, stb... A mezőgazdaságban dolgozóknál a szénában a szalmában és a gabonában szaporodó ún. raktári kukacok, atkák (storage mites) allergénjére I. típusú túlérzékenységi reakcióval reagálhatnak, rhinitis, allergiás asthma tüneteivel, melyet el kell különíteni a hipersensitiv pneumonitistől [3].

A leggyakoribb tünetek a láz, hidegrázás, köhögés, fokozott nyálkatermelés, szorító érzés és mellkasi fájdalom és kellemetlen érzés a tüdőben.

\subsection{Gombatermesztő tüdő}

1959-ben írták le először az USA-ban.

A farmertüdővel azonos klinikai tüneteket okoz. Az antigénnek két forrása van a gombakomposzt és a termesztett gomba spórája. 
A komposztkészítés elősegíti a betegséget okozó termofil, termotoleráns aktinobaktériumok nagymértékben történő elszaporodását.

A komposztálás első technológiai fázisában a mezofil szakaszt termofil váltja föl. A melegedés során a mikrobiális diverzitás csökken. Később a $60^{\circ} \mathrm{C}$ feletti (elsősorban a bunkeres komposztálás során) a mikrobiális aktivitás rohamosan csökken. A második technológiai fázis (egalizálás, pasztőrözés, kondícionálás, lehűtés) során a bunkeres hőcsúcsot kitartóképleteikkel átvészelt - aktinobaktériumok biomasszája olyan mértékben emelkedik, hogy a kitermelt komposzt szürkésfehér árnyalatú, jellegzetes illatú. Ez feltétele a csiperkegomba-szelektív komposzt elöállításának, ua. a dolgozók jelentős mértékben ki vannak téve az aktinobaktériumok által kiváltott gombatermesztő tüdőbetegségnek.

A kitermeléskor óriási tömegben van jelen a légkörben, komposzton, így az ott dolgozók (kitermelők, zsákolók, stb.) potenciálisan veszélyeztetettek.

Az expozíció másik forrása a termesztés. Ebben az esetben elsősorban az olyan gombák termesztése esetében nagyobb a veszély, ahol a piac a nyílt, félig nyílt termötesteket igényli (pl: laskagomba, shiitake, Hypsizygus [5] vagyis ahol a spóraszórás jelentős.

A csiperkegomba leggyakrabban a friss piacra, mint „zárt gomba” kerül. Ebben az esetben kevésbé vannak kitéve a megbetegedés veszélyének.

A spóraszóró gombák a hiperszenzitív pneumonitis forrásai lehetnek. Fejlettebb országokban az ilyen gombafajok szedésekor a termesztők és a komposztálásban dolgozók maszkot és más védőfelszerelést használnak.

Ez Magyarországon nem jellemző. A klinikai tünetek néhány hét vagy hónap után jelentkeznek, de leírtak már első alkalommal kialakult tüneteket is. [3]

\section{Következtetések}

Jelenleg a gombaiparban dolgozó emberek ki vannak téve különböző veszélyeknek, melyekröl nem tudnak, ezért úgy gondoljuk, hogy minden e területen dolgozó szakembernek ismernie kell a különbözö veszélyforrásokat, melyek a munkájuk során egészségkárosító hatásúak lehetnek.

Az alapanyagokkal végzett munka esetén, a komposztálás során, a termesztésben lévő szerves porok ismételt inhalációja (belégzése) által kiváltott, gyulladásos reakció következhet be.

A gombatermesztésben dolgozók, a termesztés minden fázisában ki vannak téve ezeknek a szerves poroknak.

Fontosnak tartjuk a különböző maszkok és egyéb védőfelszerelések viselését a termesztés minden fázisában, valamint a terület további kutatását, melyek elősegítik a porszennyeződés csökkentését.

\section{Szakirodalmi hivatkozások:}

[1] Uzonyi, S-né: A hazai gombacsíra-gyártás története és helyzete, Egyetemi Doktori Értekezés, KEÉ Egyetem, 1971.

[2] Fachet József, Mándi Barnabás: Az immunrendszer kórélettana, in: Kórélettan (Szollár Lajos szerk.), Semmelweis Kiadó, Budapest, 1993.

[3] Orosz M.: A hiperszenzitiv pneumonitis (HP) (extrinzik allergiás alveolitis). Klinikai immunológia (Pertányi Győző főszerk.), Medicina Könyvkiadó Rt., Budapest, 2000.

[4] Sipos R., Székely A., Berta B., Bujdosó L., Szarvas J., Hajdú Cs.: Molekuláris eljárások a gombakomposzt baktérium-népességének vizsgálatában. Magyar Gombahíradó, MGOSZ Lapja, XI. évf. 39. decemberi szám, 2003.

[5] Hiroshi Tanaka, Hiroyuki Sugawara, Toyohiro Saikai, Kazunori Tsunematsu, Hiroki Takahashi, Shosaku Abe: Mushroom Worker's Lung Caused by Spores of Hypsizigus marmoreus (Bunashimeji): Elevated Serum Surfactant Protein D Levels. Chest, Nov, 2000. 